\title{
PRINCIPLES AND FUNCTIONS OF POLITICAL MANAGEMENT
}

\author{
Nikola Vojvodić, PhD, \\ PIM University of Banja Luka, 78000 Banja Luka, +38765-549-858, nikola62@teol.net \\ Mladen M. Ivić, PhD, \\ PIM University of Banja Luka, 78000 Banja Luka, +38765-494-581, ivic.mladen@gmail.com \\ Nataša Tofil, BSc \\ in Economics, PIM University of Banja Luka, 78000 Banja Luka, +38765-723-924, \\ natasa90 t@ hotmail.com \\ Veljko Vuković, PhD, \\ PIM University of Banja Luka, 78000 Banja Luka, +38765-518-335, v.velja@gmail.com \\ Momo Komljenović, PhD, \\ Foreign Trade Chamber of Bosnia and Herzegovina, 78000 Banja Luka, +38765-625-220
}

\begin{abstract}
In the modern democratic society the politics is considered to be a skill of governing, that is, conquering and maintaining the political governance and the inevitable activity in all spheres of human activities. In the sense of negotiations the contemporary politics is "the maximal in the sphere of the possible", when, in a terrible struggle using arguments and other democratic means, one comes from the maximalistic request to the solution acceptable for both sides. Political activities would mean putting every political subject in the function of the efficient and economical satisfaction of the political needs and desires, aspirations and volitions of the political public. If the political scene is represented by the free market of political ideas, then there could be established the strategy of sensible and responsible managing in the political structures of the community, which is based on the previously researched and familiar expectations of the political public.
\end{abstract}

Key words: Politics, political parties, political management, political managers, voters, elections, social responsibility.

\section{INTRODUCTION}

Political management is a skill of managing the information as a significant resource on the political market where there are voters, current and potential members of political parties etc., whose confidence for a certain political idea and a political programme should be gained by a political party or a political person, and in that way there should be acquired the possibility for the political party to perform the political governance, i.e. to implement its political programme in the best interest of all, based on pre-election promises.

Political management is a special scientific discipline which implies the system of procedures previously specified for all campaigns or for all political candidates.

It derived from the relation of voters, as a target political segment - political parties and their political programmes, as a means of their better communication and understanding. Considering that the politicology, as a separate scientific discipline, is also concerned with the same problems, and the politics is nothing but the communication, management with its functions of planning, organising, deciding, leading and control improves that communication and unites these two scientific disciplines into one, the political management.

So,the political management is based on the principles of the classical management which could be used in leading the political parties, private or public companies and state administration.

\section{Principles of political management}

Principles are the basic form of knowledge which is helpful for better understanding of the scientific field which is under study. 
Political management, as a scientific field, must have its principles because the principles, when the management complies with them consistently, enforce the organisation of any legal subject, as well as any political party and they increase its efficiency.

There are principles in all scientific fields and so are in the political management.

The political manager must be familiar with all scientific principles, and above all, with those which he considers to be the most useful ones for leading the political party and political system.

Different theorists have defined differently the principles of the classical management which could be also used in the political management, but as modified.

For the political management the most significant principles would be:

- principle of interpersonal relations,

- principle of the quality of the political programme,

- principle of the political administration efficiency.

The first comprehensive list of the practical principles of management has been defined by Mc Callum. He has searched for the efficient system of organising for the sake of the increased efficiency of operations, and therefore he has defined six basic principles of management, and those are:

1. principle of the division of work and responsibilities,

2. granting authorization which enables performance of duties and assignments,

3. defining the system which provides the information whether the duties and assignments are performed,

4. prompt report on violations of duties which enables the troubleshooting,

5. information must not compromise the chief executives, nor decrease their reputation in front of the subordinates,

6. using the efficient system of control for discovering mistakes and nominating the responsible ones for the mistakes they have made.

Taylor has also presented his principles of management, and their target is increasing the production efficiency. He has defined four crucial principles:

1. management must consolidate and analyse the general scientific principles related to doing business,

2. workers must be carefully chosen, studied and selected so they give their maximum in the working process,

3. the worker must be inspired and qualified to use scientific methods of work,

4. management must be organised to be able to manage and perform the assignments successfully.

For the political management the basic administrative principles are the most important, and those are: ${ }^{1}$

1. Maintaining the position on the political scene is the foundation of survival and development of the political party. It is provided by improvement of the existing programme and by launching the new ones. The reliability for the position must be taken over by the managers and employees, that is, the party should adopt the marketing operational philosophy.

2. Division of functions is related to the need of specialisation of functions by the management and working activities according to the formal education and vocation, for the sake of increasing the working and management efficiency,

\footnotetext{
${ }^{1}$ Adapted by the authors according to Henri Fayol
} 
3. The political manager's authority, as the right and reliability to issue and implement the directives for performing assignments or the form of directing the subordinates by the managers,

4. Discipline represents the request aimed at the employees in the party, members and political manager to perform the assignment consistently and to cooperate with each other on demand of the working organisation,

5. Unity in giving orders - according to this principle employees should have just one superior with whom they communicate directly and whereas higher political managers don't give orders to the employees, instead a lower level political manager does it,

6. Unity in leadership- based on this principle all activities with the same goal are united and these activities are managed by one political manager. This principle enables the efficient coordination.

7. Subordination of the individual interests to the general ones - it implies that the interest of the political party is above the interest of an individual or a group and that the individual interest must be sacrificed for the general interest,

8. Development of human resources - human resources are the main carriers of political functions and it has a goal to ensure the appropriate number and structure of political managers, to increase knowledge, abilities and motivations of human resources, to work with youth and to include them actively in the realisation of the goals and assignments of the political party.

9. Rewarding - the basics of this principle is rightful and stimulative rewarding which enables satisfaction of the employees and management,
10. Centralisation - this principle demands the balance between centralisation and decentralisation, provided that planning and control are centralised and other functions decentralised.

11. Hierarchy - this principle consists of the system of giving orders, and it includes superiors and subordinates (the highest political manager doesnt give orders to the performer of the working process),

12. Order - as a principle it demands: the right people on the right positions and knowing the abilities and knowledge of the candidates for the functions,

13. Equity is a principle which demands a humane and fair relation to the employees and members because that is the way to increase the motivation and efficiency,

14. Personnel stability - this principle enhances the feeling of safety at work. A layoff must be carried out exceptionally carefully,

15. Initiative - by using this principle one stimulates the creativity, innovation and self-initiative of the employees and members of the party,

16. Spirit of togetherness - this principle ensures harmony and team work of the employees and members of the party, which enhances the organisation and work efficiency.

\section{Placement of the efficient political management}

The efficiency of the management function directly affects the work and operational efficiency of the political party. The requests for the efficient management organisation can relate to:

- introducing a new management function, or

- improvement of the existing management function. 
The new management function is introduced in the case of forming a new branch of the party (a new local, municipal or city committee, a new association, etc.).

For introducing a new management function in the organisational structure of the party one needs to:

- choose an efficient management system,

- define the span of the management,

- define the required working characteristics of the political manager,

- affirm the level of the authority and reliability of the political manager,

- define the system of monitoring of the political manager's work.

In order to realise the above mentioned one should affirm:

- the strategy of the development of the political party in which the goals, which are wanted to be achieved, are defined,

- goals for the individual functions or group of functions,

- organisational structure of the political party.

Efficiency improvement of the existing function of the political management is carried out because of the inefficiency of the existing management function and that is carried out in the whole party or some of its parts.

The reason for improvement of the political management function could be:

- a new strategy of the political party,

- turning point in the former strategy, or

- a completely new and radical change of the organisation of the political party.
Prior to introducing the new or improving the existing political management function one should:

- perform the analysis of the realised and planned development of the political party,

- perform the efficiency analysis of the existing political management function.

These analysis are the foundation for the future organisation of the political management.

\section{Span of political management}

Every political manager in the line of the management coordination has a certain number of subordinates. This number of subordinates, within one management level, is called the span of management.

The span of management can be different if:

- the number of subordinates is larger, then the span of management is wider,

- the number of subordinates is fewer, then the span of management is narrower,

Span of management should be affirmed for the whole political party and its individual parts.

Span of management also depends on the:

- form of the organisation of the political party,

- specificities of the political programme,

- way of operating,

- level of qualifications of the subordinates and

- number of subordinates or lower level managers. 


\section{Functions of political management}

The basic functions of political management are:

1. Political planning,

2. Organisation of the political party and political processes,

3. Leading or managing the political party and political processes, or

4. Coordination between the participants in the political process, from the political party to the state administration and

5. Control of work and results of the political party and members of the political party on the positions of the executive and legislative power (natural, human, financial, information and other resources).

\section{Political planning}

In the classical organisation of the political party it was considered that successful managing was only possible with a well-elaborated plan.

Planning was reserved for the political and economic elite. Planning was then regarded to have a magic power.

Classical planning is associated with:

- centralism,

- giantism,

- massive propaganda and

- universality.

Classical - traditional planning relates to the:

- long-term,

- medium-term, and

- short-term planning.
Contemporary political parties and economic companies leave the traditional planning and approach :

- strategic,

- operating and

- tactical planning.

Contemporary political management in planning must comply with the following rules:

1. Insisting on the classical planned performance should be replaced by leading daily battles:

- The priority is a planned performance on the political market,

- the plan is important, but everyday political struggles are more important,

- traditional plans are created in the bureaucratic structures with outdated information,

- the priorities are daily needs of the inhabitants, the future voters and solving their problems.

2. Intensity of the political activities mustn't dictate the planning sector of the political party, instead the activities are adapted to the everyday obligations which are derived from the election results and functions taken from the executive and legislative power.

Political top management performs the inversion of the priorities order, the political market used to be the last, but now it gains an advantage, because in the bipolar political system the opposition closely follows each and every move of the position and it uses each of the wrong moves to turn the public opinion to its own advantage.

3. Profit of the political parties includes increasing the number of 
voters and increasing the number of the party members which is gained by an ethical and moral relation of the political top management and all carriers of the lower political functions toward the voters and promises made in the pre-election campaign. The price of that all is an everyday tiring and exhausting work, at work field and at work place, which is the result of the good election results.

4. Planning does not eliminate the risk, instead it takes it over:

- it implies that planning is focused on the research of the future events and trends,

- strategic management ensures the future of the political party through planning,

- by planning, one eliminates the uncertainty and

- without a strategy it is not even possible to work at present, let alone in the future.

Every pre-election campaign must be carefully prepared. It is certainly more difficult if the elections are not held in the regular time. In that case, the political party has an assignment to carry out a short, but engaged pre-election campaign.

It is still more important that the party has a good structure. That means that the party must, also between elections, take into account the organisation and readiness for leading a campaign.

From the very beginning the campaign must be well structured and planned. The corrections often cannot be made at all.

It is also planned in which season the campaign should be held. In summer it is possible to organise activities different than those in winter which affects the equipment, advertising media, planning of manifestations and expenses.

Therefore, already at the beginning of the election year the following should be planned:

- Finance: How much money is there at your disposal? What should be financed?

- Topics: Which topics are especially important in a certain place?

- Advertising media: How to convey the topics and candidates in an optimal way?

- Manifestations:Which manifestations are the best way to address certain target groups? (The season should be taken into account!)

Only the optimal implementation of the plan provides the optimal success.

\section{Abilities of the political manager}

There are different levels of the political management. The first level of the political management is called the first-line political management. On this level the manager monitors the employees, carriers of the lower political functions and members of the party.

The second level of the political management is called the middle-line political management. On this level the political manager operates the part of the political party, for example, the municipal or city committee.

The third level of the political management is called the executive political management or the highest level of the political management. On this level the political manager coordinates the overall political process in the political party and political system, he implements the established policy up to the realisation of the goals. 
Every level of the political management has a different role in managing. From the president (as the highest level) toward the lower levels of the political management the extent of obligations decreases.

The extent of responsibilities determines the level on which the political manager performs. The higher level, the bigger responsbilities.

That means that the abilities which must be possessed by the political manager depend on the level on which he is to be engaged.

The abilities of the political manager are divided into:

- technical,

- management and

- creative ones.

Technical abilities imply that every political manager must have the knowledge of what he does. The political manager can take the role of a director or a head of the offices for some functions.

Management abilities talk about the required knowledge for performing the function of the political manager. Therefore, every political manager must have knowledge of all management functions (planning, organisation, leading, coordination and control).

Creativity talks about the ability of the political manager to separate the parts of a situation (e.g. changes in the surrounding of the political party) which affect the political party and to create and furthemore to implement a convenient defensive strategy.

The more is the creative ability required, the higher is the management level. So the political manager on the highest level must establish a relation between what happens in and out of the political party.

On the other hand, the political manager of the middle level, and especially of the lower level, follows the events in his surrounding, and his surrounding within the political party is internal.

The technical and management abilities are learned. The creative ability is partially a talent and partially experience.

Therefore, in order to be professional and successful, the political manager must have the required (high) knowledge and abilities. It is a dignified vocation for all those who dedicate themselves to organising and successful functioning of the organised ventures, such as the political party.

Who can be a political manager?

The one who wants an untroubled life, a free weekend and everyday boredom and uniformity.

The position of the political manager demands much energy, sacrifice, much time (working after regular working hours), meeting deadlines, frequent travelling, reconciliation of the opposing opinions and attitudes, making difficult and risky decisions etc.

\section{Conclusion}

Politics represents an ability to manage the country, that is, it is an established way of the social performance which should enable the realisation of the goal defined by the state, and that is creating the democratic environment for establishing the political and legal system in which citizens can adapt their needs and interests to the defined principles.

Being aware that they need a form which can enable more balanced and stable functioning of the society, the political parties must constantly develop and adapt to the new challenges of the contemporary information society.

Through the political activity, awareness, responsibility and personal performance, 
every individual can provide, satisfy and REFERENCES protect their needs, desires and preferences of the comfortable life in the community. Anyhow, it is sure that the new knowledge of the area of the political management would help them significantly in doing so. When they make decisions, political managers must take into account different social values and norms, such as: freedom of the individual, individual responsibility, human dignity, unity and justice.

All political decisions are assessed, not only for the political efficiency, but also for the political ethics.

1. Bebek B., Kolumbič A., Poslovna etika, Sinergija, Zagreb, 2000.

2. Beyme Klaus Von, Transformacija politickih stranaka, FPN, Zagreb, 2002.

3. Goati Vladimir, Savremene političke partije, Partizanska knjiga, Beograd, 1984.

4. Sartori Đovani, Stranke i stranački sustavi (Analitički okvir), Politička kultura, Zagreb, 2002.

5. Slavujević Zoran, Politički marketing, Fakultet političkih nauka, Beograd, 1999.

6. Šumpeter Jozef, (1998), Kapitalizam, socijalizam i demokratija, Plato, Beograd, 1998 